\title{
The Determinants of Happiness in Indonesia
}

\author{
Theresia Puji Rahayu, S.E., MSi' ${ }^{1,2}$ \\ Faculty of Economics and Business, University of Indonesia1) \\ Faculty of Economics and Business, Atma Jaya Catholic University of Indonesia2) \\ Email: theresiarh@gmail.com
}

Doi:10.5901/mjss.2016.v7n2p393

Abstract

This study aims to examine determinants of happiness in Indonesia. This research use cross-section IFLS data wave IV, 2007. The estimation models are Conditional Mixed Process (CMP) to address income endogeneity and Ordinal Generalized Linear Model (OGLM) to address heteroscedasticity. The result shows that the determinant of happiness in Indonesia are absolute income, relative income, education level, perceived health and some components of social capital such as willingness to help, tolerance, security, and importance of religion and religiosity in election. Moreover there is no impact of trust in same ethnic and religion people and trust in neighbors for crucial things into happiness. It indicates no discrimination over ethnic and religion in Indonesia. Demographic characteristics show that married, non-household head, urban area, non-Java-Bali islands, Islam and more religious people are happier than others. There is no difference in happiness over gender and ethnicity. Happiness-income relationship indicates Easterlin Paradox doesn't exist in Indonesia.

Keywords: happiness, endogeneity, heteroscedasticity

\section{Introduction}

Gross Domestic Products (GDP) is widely used as progress measurement and welfare indicator. But as a welfare indicator GDP has many shortcomings. It doesn't count some important things affect well-being such as externality cost, non-market activities, environmental damages, income distribution, and social relation (Van den Bergh, 2009). So that it needs alternative welfare measure called Beyond GDP. Since 1970s there are some new welfare measurements such as Human Development Index (HDI), Green GDP, Index of Social Progress, and Well-Being Index.

Bhutan is the first country that uses Gross National Happiness (GNH) to replace Gross Domestic Products (GDP) in 1970s. GNH has nine domains such as psychological well-being, health, time usage, education, cultural diversity and resilience, good governance, community vitality, ecological diversity and resilience, living standards (Ura et al., 2012). Since then, many countries give more attention on welfare index that covers more holistic components such as happiness index. It was begun in 2011 when General Assembly of United Nation invited its members to use an alternative measure of GDP. After that it is spread to England, French, Australia, Malaysia and Thailand. Indonesia began with survey on happiness measurement which was conducted by National Bureau of Statistics of Indonesia in 2013.

In Economics area Easterlin (1974) is the pioneer for happiness-income study. He found that there was income paradox (Easterlin Paradox). The paradox says that increasing income doesn't increase welfare or happiness. Clark et al. (2008) figured the happiness-income relationship in the United States as in Figure 1 below.

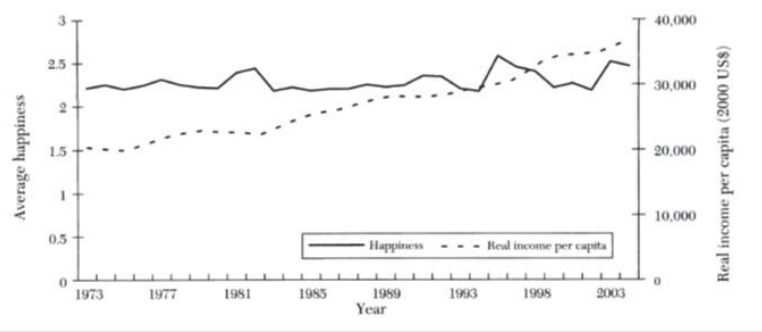

Figure 1. Happiness-real per capita income in United States 1973-2004

(Adapted from Clark et al., 2008) 
Figure 1 shows that there was increasing trend in real income per capita since 1973 to 2004 but average happiness almost did not change. It shows Easterlin Paradox in the United States economy in that period.

Easterlin Paradox implicitly informs that income isn't the only matter for happiness. There are other factors such as relative income (Clark et al. 2008), income comparison (Clark and Senik, 2011), income aspirations (Stutzer and Frey, 2010), social dimensions of human well-being (Helliwell and Putnam, 2004). Income has important role in developing countries but not in developed countries to create welfare or happiness. After basic needs are fulfilled, human beings need more than material goods such as social needs, social relation (Diener and Seligman, 2004; Kesebir and Diener, 2008) esteem, self- actualization (Sirgy, 1986).

One of traditional theory of happiness is Objective List Theory (Nussbaum, 1992; Sen, 1985 in Seligman, 2003). It tells that fulfilment of some objective list of life, such as material needs, freedom, health, education, knowledge, and friendship could produce happiness. The objective of the research is to analyze how do absolute income, relative income, education level, perceived health, social capital and demographic variables determine happiness in Indonesia. Up to now, there are few happiness research in Indonesia. There are two publications can be found namely by Sohn (2010) and by Landiyanto et al. (2011). Potential contributions from this study are in research methodology. This is the first happiness study in Indonesia that conduct Conditional Mixed Process (CMP) to address income endogeneity and Ordinal Generalized Linear Model (OGLM) to address heteroskedasticity. The organization of the paper is literature review, research method, results and discussion, and conclusion and limitations.

\section{Literature Review}

\subsection{Happiness Definition}

Happiness does not have single definition. In Sociology happiness is not different from life satisfaction (Veenhoven, 1988). Happiness is overall appreciation of one's life as a whole (Veenhoven, 2008), which makes human beings feel positive and pleasure. These definitions are in line with Bentham's concept of happiness, that is, the sum of pleasures and pains. In Psychology, happiness is different from life satisfaction. Happiness is part of subjective well-being. Subjective well-being is well-being condition within long duration that has affective and cognitive aspects. Kahneman (1999) said that well-being consisted of pleasure or happiness. However, in Economics, happiness is not different from subjective well-being, satisfaction, utility, well-being, or welfare (Easterlin, 1995).

Happiness concept is not truly new in Indonesian life. According to Kamus Besar Bahasa Indonesia, a prominent dictionary in Indonesia, happiness is pleasure and tranquility within body and soul, luck, fortune. This definition is in line with the happiness concept in Javanese culture. Suryomentaram, a famous Javanese philosopher, stated that happiness is the circumstances with tranquility, intimate, harmonious, free from improper wants.

\subsection{Happiness Theory}

Veenhoven (2006) classifies happiness theory into three groups. First, Set-Point Theory which states that happiness is programmed by someone and doesn't connect with any circumstances. It is because happiness is affected by personal trait, genetic, and culture. Secondly, Cognitive Theory which states that happiness is a product of thinking and human reflection towards differences between what is in real life and should be in life. Happiness is uncountable but recognizable. Third, Affective Theory which states that happiness is human reflection about how good is the life. Feeling fine tells happy life.

Seligman (2003) classifies three traditional theories of happiness i.e. Hedonism Theory, Desire Theory, and Objective List Theory. Hedonism Theory tells that happiness is about how to maximize pleasure and minimize pain. It's about a person's positive experience. The theory is modern version on Bentham Utilitarianism. Desire Theory states that happiness links with fulfilment of personal desires. It is better than hedonism. Objective List Theory states that happiness will come from fulfilment of objectives of life such as material needs, freedom, health, education, knowledge, and friendship.

\subsection{Happiness-Income Relationship}

Increasing income does not always followed by increasing in happiness. Tian and Yang (2007) show that income increase will increase happiness till maximum level of happiness reached. There is a critical income where happiness reach maximum level. Afterwards increasing in income will not increase happiness. It is called as Easterlin Paradox. In 
order to enhance happiness level it needs extension in non-income factor.

One possible source of Easterlin Paradox is income aspiration (Stutzer, 2004). There are two explanations for income aspiration. First, income increasing only raises well-being temporarily. Then adaptation process will make wellbeing remain unchanged. It was called as hedonic adaptation or hedonic treadmill (Brickman and Campbell 1971 in Clark et al, 2008). Second, there is income comparison or relative income or social comparison (Clark, et al., 2008). Third, income expectation. Higher income expectation higher income aspiration (Mc. Bride, 2010). Easterlin (2001) shows that increasing in income will increase aspiration income as figured out below.

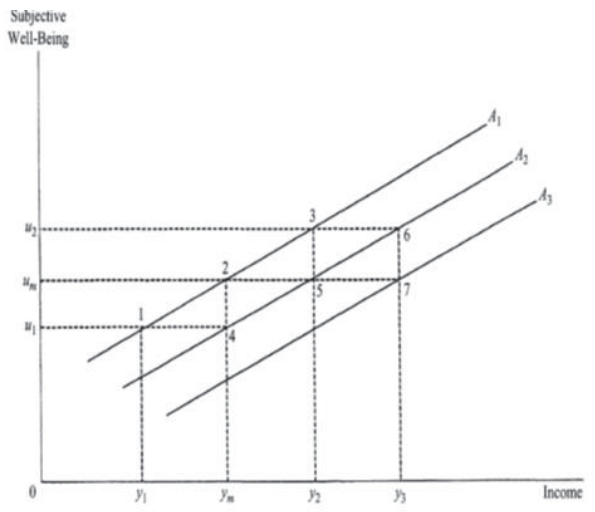

Figure 3. Subjective Well-being and Income Aspiration

(Adapted from Easterlin, 2001).

Income increasing from $y_{m}$ to $y_{2}$ will not increase happiness level from $u_{m}$ to $u_{2}$ because of increase in aspiration income level from $A_{1}$ to $A_{2}$. So that income increasing will make happiness level remain constant at $u_{m}$.

\subsection{Empirical Review}

Happiness-income relationship first explored by Easterlin (1974). His study have shown that income-happiness had positive relation in one point of time but not for over time. It is called happiness paradox or Easterlin paradox. One possible source of Easterlin Paradox is income aspiration (Easterlin, 2001) or relative income (Blanchflower and Oswald, 2004; Clark et al., 2008) or income comparison (Clark and Senik, 2011). Some researchers found that there is happinessincome positive relationship (Blanchflower and Oswald, 2004); Stevenson and Wolfers, 2008). On the other side, some researchers argued that income will continue raise until a certain level and then tends to decrease or remain unchanged. Stevenson and Wolfers (2013) said that the existence of threshold income is widely claimed although there is no statistical evidence presented. They have summarized some threshold income from some articles which between range $\$ 8,000$ - \$25,000 (Di Tella and McCulloch, 2008), \$15,000 (Layard, 2003), \$20,000(Layard, 2005), \$10,000 (Frey and Stutzer, 2002).

Usually education-happiness and health-happiness have positive relationship. Michalos (2008), Chen (2012) and Cunado and Garcia (2012) show that education level does not affect happiness directly. It has indirect channel through network (social capital) or through self-confidence and self-estimation. Health-happiness relationship found by Green and Elliot (2010) through intermediate variable. They found that higher religiosity make more healthy and happy. Singer et al. (1999) said decreasing in health with increasing age do not make someone unhappy because of mental maturity. Someone that become unemployed may have decrease in health and it becomes worst for non-volunteer (Dave et al., 2008).

Social capital-happiness relationship could be seen from trust within community. Helliwell (2007) found that higher social capital lower suicide and higher subjective well-being. Interpersonal mistrust made unhappiness (Tokuda and Inoguchi, 2008). Non market relational goods such as trust in individual, membership, trust in institution make higher life satisfaction (Sarracino, 2012). 


\section{Research Method}

\subsection{Data}

This research use Indonesia Family Life Survey (IFLS) data wave 4, 2007. The cross-section data is part of longitudinal survey on 13.535 household in 13 provinces in Indonesia with 17.650 observations. The provinces are North Sumatera, West Sumatera, South Sumatera, Lampung, DKI Jakarta, West Java, Central Java, Yogyakarta, East Java, Bali, West Nusa Tenggara, South Kalimantan and South Sulawesi.

\subsection{Empirical Strategy}

Happiness was measured with question "Taken all things together how would you say things are these days - would you say you were very happy, pretty happy or not too happy?" The ordered answers then re-ordered into 1. Very unhappy 2. Unhappy 3. Happy 4. Very happy. Household per capita expenditures is proxy for absolute income per capita. It includes expenditure for food, non-food, education, own produced goods in real term (constant price in 2000). Relative income is ratio absolute income per capita and mean income. Education level is highest education level had ever attended. We classify the education data into two groups so we have one dummy variable 0 for low education level (elementary school) and 1 for higher education level (Junior High School and higher). Perceived health status measured by three questions (1) In general, how is your health in general? (2) Compared with your health 12 months ago, how is your health now? (3) Compared to another person of your age and sex, how is your health now? Each of them is in dummy variable, 0 for low perceived healthy level and 1 for high perceived healthy level. There are six sub groups of social capital namely Willingness to help, Trust- Ethnic, Trust-Neighbors, Safety, Tolerance, and Election.

One problem has to be concerned is endogeneity due to correlation between error and independent variable. Endogeneity may results bias and inconsistent parameter. Powdthavee (2008) address income endogeneity using some instrumental variables. This research use side job and schooling years as instrumental variables. This study conducts Conditional Mixed Process (CMP) method to estimate parameters in the right hand side model. The CMP method was chosen because this method could address endogeneity in the estimation model. According to Rodman (2011) CMP is appropriate for two types of estimation situations. First, estimation in which a truly recursive data-generating process is posited and fully modeled. Secondly, estimation in which there is a simultaneity but instruments allow as in two stage least squares (2SLS).

This study use cross-section data which has potential heteroscedasticity problem. When error variances are not the same for all cases, the standard errors are wrong and the parameters are biased (Williams, 2010 from Yatchew and Griliches, 1985). This research adopt Ordinal Generalized Linear Model (OGLM) which can be used to estimate ologit, oprobit or hetprob (Williams, 2010). OGLM is a general method to estimate heterogeneous choice or location scale or heteroscedastic ordered model. If so OGLM is an appropriate method to address heteroscedasticity problem in the estimation model.

The empirical model is:

$Y_{i}=\alpha+\beta_{1} X_{1 i}+\beta_{2} X_{2 i}+\beta_{3} X_{3 i}+\beta_{4} X_{4 i}+\beta_{5} X_{5 i}+\beta_{6} X_{6 i}+\varepsilon$

where

$Y_{i}$ : happiness,

$X_{1 i}$ : absolute income,

$X_{2 i}$ : relative income,

$X_{3 i}$ : percieved health vector,

$X_{4 i}$ : education level,

$X_{5 i}:$ social capital vector,

$X_{6 i}:$ vector of demographic characteristics. Subsripct i shows data for ithperson.

$\varepsilon$ : error term

\subsection{Estimation Methods}

\subsubsection{Conditional Mixed Process (CMP)}

Conditional Mixed Process (CMP) is working within simultaneous equation system. It has two properties (Roodman, 2011). First, recursive which refers to multi stages estimation within simultaneous equation system. Second, full 
observability refers to right hand side endogeneous variable which is full observable.

Roodman (2015) stated CMP estimates multi-equation, mixed-process models and potentially existing hierarchy random effect. Mixed process means that different equation could have different dependent variable. The alternatives model are continuous (OLS), tobit, probit and ordered probit. Conditional means that model could be variable from many observations. Dependent variable in one equation could be independent variable in other equation. This dependency should have one recursive structure if dependency within censor observed variable and could be separated into many stages. If dependency in latent variable it will enter to simultaneous structure. CMP will be fit in SUR, simultaneous equation and instrumental variable model.

\subsubsection{Heterogeneous Choice Model or Ordinal Generalized Model (OGLM)}

Williams (2010) argues Heterogeneous Choice Model or Ordinal generalized Model (OGLM) able to address heteroscedasticity in logistic regression.

For a latent - model

$Y_{i}^{*}=\alpha_{0}+\alpha_{1} X_{i 1}+\cdots+\alpha_{k} X_{i k}+\sigma \varepsilon_{i}$

$\varepsilon_{i}$ : Error term under either logistic or normal distribution.

Then $\sigma$ is residual variance which equal to $\frac{\pi^{2}}{3}$ for logit and 1 for probit model.

When $Y^{*}$ is Latent variable that unobserved, true estimation is not for $\alpha$ but $\beta$.

Allison (1999; in Williams, 2010) states $\beta_{k}=\alpha_{k} / \sigma$ which $k: 1,2, \ldots, K$.

If $\sigma$ is not different for all cases residual will be homoscedastic and $\beta / \alpha$ ratio is not different for all cases either. But if there is $\sigma$ variability Heterogeneous Choice Model could be applied.

The model solve next two equation simultaneously:

Outcome or choice equation:

$Y_{i}^{*}=\sum_{k} X_{i k} \beta_{k}+\varepsilon_{i}$

Variance-equation:

$\sigma_{i}=\exp \left(\sum_{j} z_{i j} \gamma_{j}\right)$

\section{Results}

\subsection{Descriptive Analysis}

This study uses 17,650 observations. Some demographic characteristics are $58.90 \%$ male, $75.50 \%$ are married, $47.56 \%$ are household head, $42.68 \%$ are Javanese, $52.72 \%$ live in urban area, more than 50\% from West Java, Central Java and East Java province. From education level there are 37\% people with elementary school, 14.4\% junior high school, 26\% senior high school and only $11.84 \%$ undergraduate level. Most of respondents are Moslem i.e. 89.20\%, age between 1564 years old and mean age is 35 years. Income per capita lies between IDR 21,740.00 - IDR 13600,000.00 with mean IDR $574,248.00$. Most Indonesian people are happy, $85.58 \%$, and very happy $6.35 \%$, unhappy $7.73 \%$ and very small people are very unhappy $0.34 \%$.

\subsection{Estimation Result}

This research using Side job and Schooling years as instrumental variables. Both of them are indicated as valid instrumental variable based on overidentification test (Wu-Hausman and Durbin-Wu-Hausman test). Regression model to address endogeneity within ordered response model is Conditional Mixed Process (CMP). Here the estimation result with CMP model.

Tabel 1: Conditional Mixed Process Result Estimation

\begin{tabular}{|l|l|l|}
\hline Predictors & Regression Coefficient & $\mathrm{p}$-value \\
\hline Ln Y & 0.687 & 0.000 \\
& $(0.061)$ & \\
\hline$Y \bar{Y}$ & 0.040 & 0.040 \\
\hline $\bar{Y}$
\end{tabular}




\begin{tabular}{|c|c|c|}
\hline & $(0.019)$ & \\
\hline Age & $\begin{array}{l}-0.035 \\
(0.006)\end{array}$ & 0.000 \\
\hline Age2 & $\begin{array}{l}0.0003 \\
(0.00007)\end{array}$ & 0.000 \\
\hline Woman & $\begin{array}{l}0.023 \\
(0.027)\end{array}$ & 0.388 \\
\hline Household Head & $\begin{array}{l}-0.060 \\
(0.028)\end{array}$ & 0.029 \\
\hline Married & $\begin{array}{l}0.460 \\
(0.031)\end{array}$ & 0.000 \\
\hline Urban & $\begin{array}{l}0.051 \\
(0.022)\end{array}$ & 0.022 \\
\hline Java & $\begin{array}{l}0.024 \\
(0.022)\end{array}$ & 0.270 \\
\hline Java - Bali & $\begin{array}{l}-0.090 \\
(0.023)\end{array}$ & 0.000 \\
\hline Islam & $\begin{array}{l}0.170 \\
(0.036)\end{array}$ & 0.000 \\
\hline Religiosity & $\begin{array}{l}0.175 \\
(0.026)\end{array}$ & 0.000 \\
\hline Junior High School & $\begin{array}{l}-0.061 \\
(0.035)\end{array}$ & 0.087 \\
\hline Healthy & $\begin{array}{l}0.180 \\
(0.036)\end{array}$ & 0.000 \\
\hline Healthy - now & $\begin{array}{l}0.140 \\
(0.034)\end{array}$ & 0.000 \\
\hline Healthy - others & $\begin{array}{l}0.240 \\
(0.050)\end{array}$ & 0.000 \\
\hline Willingness to help & $\begin{array}{l}0.123 \\
(0.035) \\
\end{array}$ & 0.000 \\
\hline Trust-ethnic & \begin{tabular}{|l|}
0.014 \\
$(0.027)$ \\
\end{tabular} & 0.605 \\
\hline Trust-neighbors & $\begin{array}{l}0.019 \\
(0.015) \\
\end{array}$ & 0.204 \\
\hline Safety & $\begin{array}{l}-0.205 \\
(0.037) \\
\end{array}$ & 0.000 \\
\hline Tolerance & $\begin{array}{l}0.077 \\
(0.032)\end{array}$ & 0.017 \\
\hline Election & $\begin{array}{l}-0.032 \\
(0.013) \\
\end{array}$ & 0.017 \\
\hline
\end{tabular}

Note: Robust standard error in parentheses

Conditional Mixed Process model shows happiness predictors are income, education, health and some social capital components. Those predictors have positive impact on happiness. Demographic characteristics show happier people are married, non - household head, located in urban area, non - Java - Bali islands, Islam and more religious people. There is no different happiness feeling between various gender and background ethnicity. All predictors are robust except Relative Income, Junior High School, Woman, and Java.

Brant test after ologit regression is used to detect heteroskedasticity source. The violation from parallel regression assumption could be source of heteroscedasticy problem. Brant test shows some predictors are violate parallel regression assumption i.e. Ln $Y, \frac{Y}{\bar{Y}}$, Married, Junior High School, Healthy, Healthy-other, Willing to help, Trust-ethnic, and Safety. Ordinal Generalized Linear Model (OGLM) is used to address heteroskedasticy problem. 
Table 2: Ordinal Generalized Linear Model Result Estimation

\begin{tabular}{|c|c|c|}
\hline Predictors & Regression Coefficient & p-value \\
\hline $\operatorname{Ln} Y$ & $\begin{array}{l}0.045 \\
(0.014) \\
\end{array}$ & 0.002 \\
\hline$\frac{Y}{\bar{Y}}$ & $\begin{array}{l}0.011 \\
(0.006)\end{array}$ & 0.088 \\
\hline Age & $\begin{array}{l}-0.008 \\
(0.003) \\
\end{array}$ & 0.003 \\
\hline Age2 & $\begin{array}{l}0.0006 \\
(0.00003) \\
\end{array}$ & 0.017 \\
\hline Woman & $\begin{array}{l}0.005 \\
(0.007) \\
\end{array}$ & 0.475 \\
\hline Household Head & $\begin{array}{l}-0.017 \\
(0.009)\end{array}$ & 0.056 \\
\hline Married & $\begin{array}{l}0.122 \\
(0.032)\end{array}$ & 0.000 \\
\hline Urban & $\begin{array}{l}0.021 \\
(0.008)\end{array}$ & 0.009 \\
\hline Java & $\begin{array}{l}0.007 \\
(0.006)\end{array}$ & 0.262 \\
\hline Java - Bali & $\begin{array}{l}-0.026 \\
(0.009) \\
\end{array}$ & 0.005 \\
\hline Islam & $\begin{array}{l}0.043 \\
(0.015)\end{array}$ & 0.004 \\
\hline Religiosity & $\begin{array}{l}0.048 \\
(0.014)\end{array}$ & 0.001 \\
\hline Junior High School & $\begin{array}{l}0.044 \\
(0.013)\end{array}$ & 0.001 \\
\hline Healthy & $\begin{array}{l}0.045 \\
(0.015) \\
\end{array}$ & 0.003 \\
\hline Healthy - now & $\begin{array}{l}0.040 \\
(0.014)\end{array}$ & 0.003 \\
\hline Healthy - others & $\begin{array}{l}0.054 \\
(0.020)\end{array}$ & 0.006 \\
\hline Willingness to help & $\begin{array}{l}-0.038 \\
(0.014)\end{array}$ & 0.006 \\
\hline Trust-ethnic & $\begin{array}{l}0.003 \\
(0.007)\end{array}$ & 0.683 \\
\hline Trust-neighbors & $\begin{array}{l}0.007 \\
(0.004)\end{array}$ & 0.118 \\
\hline Safety & $\begin{array}{l}-0.059 \\
(0.004)\end{array}$ & 0.001 \\
\hline Tolerance & $\begin{array}{l}0.017 \\
(0.009)\end{array}$ & 0.078 \\
\hline Election & $\begin{array}{l}-0.009 \\
(0.004)\end{array}$ & 0.032 \\
\hline \multicolumn{3}{|l|}{ Variance Equation } \\
\hline $\operatorname{Ln} Y$ & $\begin{array}{l}-0.036 \\
(0.020) \\
\end{array}$ & 0.076 \\
\hline$\frac{Y}{\bar{Y}}$ & $\begin{array}{l}0.049 \\
(0.015)\end{array}$ & 0.001 \\
\hline Married & $\begin{array}{l}-0.067 \\
(0.017) \\
\end{array}$ & 0.000 \\
\hline Islam & $\begin{array}{l}-0.026 \\
(0.023)\end{array}$ & 0.252 \\
\hline Junior High School & $\begin{array}{l}-0.034 \\
(0.015) \\
\end{array}$ & 0.023 \\
\hline Healthy & -0.070 & 0.001 \\
\hline
\end{tabular}




\begin{tabular}{|l|l|l|}
\hline & $(0.022)$ & \\
\hline Healthy-others & -0.131 & 0.000 \\
& $(0.031)$ & \\
\hline Willingness to Help & -0.187 & 0.000 \\
& $(0.021)$ & \\
\hline Trust-ethnic & -0.046 & 0.006 \\
& $(0.007)$ & \\
\hline Safety & -0.121 & 0.000 \\
& $(0.022)$ & \\
\hline
\end{tabular}

Note: Robust standard error in parentheses

Ordinal Generalized Linear model result estimation shows income, relative income, education, health and social capital have significant effect on happiness. Significant demographic characteristics are age, non-household head, married, Java, Java- Bali, Islam, and religiosity. There is not difference in happiness between woman and man and also from various ethnical background. All predictors are robust except $\frac{Y}{\bar{Y}}$, Woman and Java.

Marginal effect measures effect a unit changing in predictor on a unit probability changing in dependent variable. The sign of marginal effect almost no different between CMP and OGLM model except independent variable $\frac{Y}{\bar{Y}}$ and Safety.

Table 3: Marginal Effect

\begin{tabular}{|c|c|c|c|c|c|c|c|c|}
\hline \multirow[t]{2}{*}{ Predictors } & \multicolumn{2}{|c|}{ Very unhappy } & \multicolumn{2}{|c|}{ Unhappy } & \multicolumn{2}{|c|}{ Hарру } & \multicolumn{2}{|c|}{ Very Happy } \\
\hline & CMP & OGLM & CMP & OGLM & CMP & OGLM & CMP & OGLM \\
\hline $\operatorname{Ln} Y$ & -0.0071 & -0.0013 & -0.0957 & -0.0290 & 0.0168 & 0.0174 & 0.0860 & 0.0129 \\
\hline $\begin{array}{l}\bar{Y} \\
\overline{\bar{V}}\end{array}$ & -0.0005 & 0.0005 & -0.0055 & 0.0033 & 0.0009 & -0.0169 & 0.0050 & 0.0131 \\
\hline Age & 0.0004 & 0.0001 & 0.0049 & 0.0041 & -0.0008 & -0.0007 & -0.0044 & -0.0035 \\
\hline Age2 & $-3.08 \mathrm{e}-06$ & $-1.19 e-06$ & -0.00004 & -0.00003 & $7.29 \mathrm{e}-06$ & $5.90 \mathrm{e}-06$ & 0.0003 & 0.0003 \\
\hline Woman * & -0.0002 & -0.00009 & -0.0032 & -0.0026 & \begin{tabular}{|l|}
0.0005 \\
\end{tabular} & \begin{tabular}{|l|}
0.0005 \\
\end{tabular} & 0.0029 & 0.0022 \\
\hline Household Head * & 0.0006 & 0.0003 & 0.0084 & 0.0083 & -0.0015 & -0.0016 & -0.0075 & -0.0071 \\
\hline Married * & -0.0067 & -0.0057 & -0.0742 & -0.0856 & 0.0325 & 0.0573 & 0.0485 & 0.0340 \\
\hline Urban * & -0.0005 & -0.0004 & -0.0071 & -0.0101 & 0.0012 & 0.0020 & 0.0063 & 0.0090 \\
\hline Java * & -0.0002 & -0.0001 & -0.0034 & -0.0033 & 0.0006 & 0.0006 & 0.0031 & 0.0030 \\
\hline Java-B & 0.000 & & 0.0123 & 0.0127 & -0.0018 & -0.0019 & -0.0114 & -0.0113 \\
\hline Islam * & -0.0021 & -0.0015 & -0.0257 & -0.0287 & 0.0086 & 0.0178 & 0.0192 & 0.0125 \\
\hline Religiosity * & -0.0021 & -0.0011 & -0.0259 & -0.0263 & 0.0077 & 0.0084 & 0.0204 & 0.0190 \\
\hline Junior High School * & 0.0006 & -0.0014 & 0.0084 & -0.0291 & -0.0013 & 0.0179 & -0.0077 & 0.0126 \\
\hline Healthy * & -0.0022 & -0.0027 & -0.0273 & -0.0386 & 0.0092 & 0.0352 & 0.0203 & 0.0061 \\
\hline Healthy - now * & -0.0017 & -0.0092 & -0.0209 & -0.0221 & 0.0064 & 0.0074 & 0.0162 & 0.0157 \\
\hline Healthy - & -0.0033 & & -0.0383 & -0.0565 & 0.0160 & 0.0632 & 0.2555 & -0.0009 \\
\hline Willingn & 0.001 & & 0.0172 & -0.0147 & -0.0030 & 0.0652 & -0.0155 & -0.0486 \\
\hline Trust-e & -0.0001 & -0.0007 & -0.0019 & -0.0098 & 0.0003 & 0.0172 & 0.0017 & -0.0067 \\
\hline Trust-neighb & -0.0002 & -0.0001 & -0.0027 & -0.0035 & 0.0005 & 0.0006 & 0.0024 & 0.0030 \\
\hline Safety & 0.0021 & -0.0006 & 0.0286 & 0.0074 & -0.0050 & 0.0393 & -0.0257 & -0.0461 \\
\hline Tolerance & -0.0008 & -0.0003 & -0.0107 & -0.0084 & 0.0019 & 0.0016 & 0.0096 & 0.0072 \\
\hline Election & 0.0003 & 0.0002 & 0.0045 & 0.0046 & -0.0008 & -0.0009 & -0.0041 & -0.0039 \\
\hline
\end{tabular}

*) Dummy variable

\section{Discussion}

From estimation result using CMP and OGLM known that happiness determinants in Indonesia are absolute income, relative income, education, health and social capital. Some components of social capital such as trust in same ethnic and trust in neighbors do not have significant effect on happiness. All significant predictors have positive impact on happiness.

Increasing in absolute income will increase happiness. It indicates no Easterlin Paradox in Indonesia. The result is common phenomenon in developing countries. Indonesia mean per capita income in 2007 is IDR 500,000.00. It means Indonesia is one of developing countries which usually Easterlin Paradox doesn't exist. Easterlin Paradox exists in one 
point time but not in over- time income-happiness relationship. This study use cross-section data which has little possibility for existing Easterlin Paradox. Relative income also has positive significant impact on happiness. It means income increasing will increase relative economic position in society and so do happiness.

Feeling healthier makes happier. Without health problem people will more productive so that he could earn more money or save more money for another things that make him happier. From three health measures, health comparison to others has biggest impact on happiness. Better relative health ensure better health. Feeling healthy and health comparison between current and last year also have positive relationship with happiness.

Increasing in education level will increase happiness. Higher education will increase opportunity for broader networking and employment (Chen, 2012). It also open wider better job with better income and higher happiness (Cunado and Gracia, 2012). Moreover education could be used as earning proxy by economist (Blanchflower and Oswald, 2004). Higher education cause higher income and higher happiness.

Social capital has significant effect on happiness. Willingness to help, safety, and tolerance give positive impact on happiness. Higher willingness to help will increase happiness. It implies "Gotong Royong" culture in Indonesia society. Higher safety will increase happiness. It reflects higher security in certain area. People have more safety to do some activities until lately night without worry. More tolerance in religion diversity will increase happiness. It make more tight social cohesion. It also reflects no discrimination in Indonesia. Higher Election will decrease happiness. It means that religion and religiosity belongs to candidates are still matter for voting in election. Some social capital component, Trustethnic and Trust-neighbors, do not have significant effect to happiness. Trust-ethnic means more have trust in same ethnic and religion. If it is not significant, it means no tendency for discrimination over religion and ethnic. No Trustneighbors means people can't give trust to neighbors for some crucial things like taking care their children and house.

Demographic characteristics give some pictures of Indonesian people characteristic. Married people are happier than unmarried (not married, dead or alive divorce). Marriage make good interpersonal relationship between husband and wife and emotional supporting in facing problems. These are appropriate with protection support hypothesis (Coombs, 1991), through emotional support or financial support and improvement health (Stack and Eshleman, 1998). It was called social causation or marriage protection hypothesis. There is no difference in women and men happiness. There is no specific theory for happiness over gender. Akerlof and Kranton (2000) propose gender identity hypothesis about job characteristics. Men should not do domestic works and have to earn more money than women.

People live in urban area are happier than in rural area. This finding is different with other research. People live in rural area usually happier than in urban area. Better environment quality, better social engagement and more peaceful life in rural (Smyth et al, 2011). On the other hand rural people may have worse life than urban people because of lower income, public transportation, and health quality (Youmans, 1977). They need much more public goods providing (Jongudomkarn and Camfield, 2006). The data show that 73.24 percent of rural people have income lower than IDR $500,000.00$ per month but only 49.74 percent for urban people. It shows that income belongs to urban people higher than rural people do. This finding explain why rural people have lower happiness than urban people. People in Java-Bali islands are unhappier than others. One possible cause is population pressure in there. Most Indonesian people live in Java (57.5 percent) and Bali (5 percent) ${ }^{1}$. With highest population density is in DKI Jakarta i.e. 14.440 per km2. Moreover there are higher pressures on natural resources and ecosystem in Java (Repetto, 1986). These problems make people in Java-Bali islands have lower happiness than others.

Moslems are happier than others. This findings may not tell the fact because there is very few sample data for nonmoslems (10 percent). Religion might be matters for happiness but not for religiosity. Religious people are happier than others. More religious someone is healthier mental and less depressed he is (Chamberlain and Zika, 1988; Green and Elliot, 2010). Religious people usually have tight engagement in religious activity therefore they get huge social support and network (Lim and Putnam, 2010).

Happiness-age relationship indicates a U-shaped curve. Happiness decrease in age and its lowest point is about 58 years from CMP and 66 years from OGLM estimation. It means that people feel the lowest happiness at 60-70 years old. Possible sources of unhappiness is health problem when people getting older and be poor (Nuegarten dan Nuegarten, 1986). Health cost is expensive enough for most of them.

From marginal effect of Conditional Mixed Process (CMP), increasing in 1 percent absolute income will decrease one unit probability of very unhappy and unhappy but increase one unit probability of happy and very happy. For relative income, increasing relative income will increase probability of very happy and happy but decreasing probability of very unhappy and unhappy. For education level, increasing in education level will increase a unit probability of very unhappy and unhappy but decreasing one unit probability of happy and very happy. The result is rather confusing. One dummy

${ }^{1}$ Census of Population, National Bureau of Statistics of Indonesia, 2010. 
variable in education level couldn't give clearer its true impact. For health perceived, increasing health perceived will increase one unit probability happy and very happy and decreasing a unit probability very unhappy and unhappy.

For social capital components Willingness to help, more disagree to help others more probability to be very unhappy and unhappy and less probability to be happy and very happy. For Trust- ethnic, more disagree to give more trust to same ethnic and religion people, more probability to be happy and very happy but less probability to be very unhappy and unhappy. For Trust-neighbors, more distrust to neighbors less probability to be very unhappy and unhappy but more probability to be very happy and happy. For Safety, more safety more probability to very happy and happy and less probability to be very unhappy and unhappy. For Tolerance, more tolerance more probability to be very happy and happy but less probability to be very unhappy and unhappy. For Election, more important candidate's religion and religiosity in voting in more probability to be very happy and happy but less probability to be very unhappy and unhappy.

From demographic variables provide various happiness information. First, increasing in age followed by increasing in probability very unhappy and unhappy but decreasing probability of very happy and happy. Second, married, nonhousehold head, live in urban area, non- Java- Bali island, Javanese, Islam and more religious people has more tendency to be very happy and happy but less tendency to be very unhappy and unhappy than men.

\section{Conclusion and Limitations}

The estimation models are Conditional Mixed Process (CMP) to address income endogeneity and Ordinal Generalized Linear Model (OGLM) to address heteroscedasticity. The result show that determinant of happiness in Indonesia are absolute income, relative income, education level, perceived health and some components of social capital such as altruistic behavior i.e. willingness to help others, tolerance, and also security, importance of religion and religiosity in election. Moreover there is no impact of trust in same ethnic and religion people and trust in neighbors for crucial things into happiness. It indicates no discrimination over ethnic and religion in Indonesia. Demographic characteristics show that married, non- household head, urban area, non- Java -Bali islands, Islam and more religious people are happier than others. There is no difference in happiness over gender and ethnicity. Positive impact of absolute income on happiness implies no Easterlin Paradox in Indonesia. Moreover absolute income is the most important factor for Indonesian happiness. This result is in line with other research in developing countries. Happiness-age relationship looks like Ushaped curve with lowest point at 58 and 66 years old from CMP and OGLM estimation respectively. There is almost no different marginal effects measurement from CMP and OGLM except for gender (Woman) and ethnicity (Java) variable.

The study has some limitations. First, the study use cross-section data therefore the results could not capture happiness in many points of time. Secondly, benchmark of relative income is mean of income over all observations. It could not figure relative position over region. Third, the study lacks of empirical reviews support due to lack of usage CMP and OGLM model in happiness studies. For further research in Indonesia, the scholars could use panel data and more explanatory variables to capture holistic approach in determining Indonesian happiness.

\section{Acknowledgement}

This paper is part of PhD research which is funded by Atma Jaya Catholic University of Indonesia.

The author thank to the PhD supervisors i.e. Prof. Dr. Dorodjatun Kuntjoro Jakti, Dr. Sonny Harry B. Harmadi and Dr. Mahyus Ekananda from Faculty of Economics and Business, University of Indonesia.

\section{References}

Akerlof, G.A., \& Kranton, R.E. (2000). Economics and Identity. Quarterly Journal of Economics, 115(3), 715-753.

Blanchflower, D.G., \& Oswald, A.J. (2004). Well-being overtime in Britain and USA. Journal of Public Economics, 88, $1359-1386$.

Chamberlain, K., \& Zika, S. (1988). Religiosity, Life Meanings and Wellbeing: Some Relationships in a sample of Women. Journal for the Scientific Study of Religion, 27, 411-420.

Chen, W. (2012). How Education Enhances Happiness: Comparison of Mediating Factors in Four East Asian Countries. Social Indicators Research, 106(1), 117-131.

Clark, A.E., \& Senik, C. (2011). Will GDP Growth Increase Happiness in Developing Countries? The Institute for the Study of Labor (IZA) Bonn, Discussion Paper 5595.

Clark, A.E., Frijters, P., \& Shields, M.A. (2008). Relative Income, Happiness and Utility: An Explanation for the Easterlin Paradox and Other Puzzles. Journal of Economic Literature, 46(1), 95-144.

Coombs, R.H. (1991). Marital Status and Personal Well-Being: A Literature Review. Family Relations, 40(1), 97-102.

Cunado, J., \& de Garcia, F.P. (2012). Does Education Affect Happiness? Evidence for Spain. Social Indicators Research, 108(1), 185- 
195.

Dave, D., Rashad, I., \& Jasmina S. (2008). The Effects of Retirement on Physical and Mental Health on Outcomes. Southern Economic Journal, 75(2), 479-523.

Diener, E., \& Seligman, M.E.P. (2004). Beyond Money: Toward an Economy of Well-Being. Psychological Science in the Public Interest, $5(1), 1-31$.

Di Tella, R., \& McCulloch, R. (2006). Some Uses of Happiness Data in Economics. The Journal of Economic Perspectives, 20(1), 25-46.

Easterlin, R.A. (1974). Does Economic Growth Improve the Human Lot? In: Paul AD, Reder MW (eds) Nations and Households in Economic Growth: Essays in Honour of Moses Abramovitz. New York: Academic Press.

-------. (1995). Will Raising the Incomes of All Increase the Happiness of All? Journal of Economic Behavior and Organization, 27, 3547.

. (2001). Income and Happiness: Towards a Unified Theory. The Economic Journal, 111, 465-484.

Frey, B.S., \& Stutzer, A. (2002). What can Economists Learn from Happiness Research? The Journal of Economic Literature, 40(2), 402-435.

Green, M., \& Elliott, M. (2010). Religion, Health, and Psychological Well-Being. Journal of Religion and Health, 49, 149-163.

Helliwell, J.F. (2007). Well-Being and Social Capital: Does Suicide Pose a Puzzle?. Social Indicators Research, 81(3), 455-496.

Helliwell, J.F., \& Putnam, R.D. (2004). The Social context of Well-Being. Philosophical Transactions: Biological Sciences, The Science of well-Being: Integrating Neurobiology, Psychology and Social Science, 359 (1449), 1436-1446.

Jongudomkarn, D., \& Camfield, L. (2006). Exploring the Quality of Life of People in North Eastern and Southern Thailand. Social Indicators Research, 78(3), 489-529.

Kahneman, D. (1999). Objective Happiness. In: Kahneman D, Diener E, Schwarz N (eds) Well-being: The Foundation of Hedonic Psychology (pp 3-25). New York: Russel Sage Foundations.

Kesebir, P., \& Diener, E. (2008). In Pursuit of Happiness: Empirical Answers to Philosophical Questions. Perspectives on Psychological Science, 3(2), 117-125.

Landiyanto, E.A., Ling, J., Puspitasari, M., \& Irianti, S.E. (2011). Wealth and Happiness: Empirical Evidence from Indonesia. Chulalongkron Journal of Economics, 23, 1-17.

Layard, R. (2003). Happiness: Has Social Science a Clue. Lionel Robbins Memorial Lectures, London School of Economics.

----. (2005). Happiness: Lessons from a New Science. London: Penguin.

Lim, C., \& Putnam, R.D. (2010). Religion, Social Networks and Life Satisfaction. American Sociological Review, 75(6), 914-933.

McBride, M. (2010). Money, Happiness, and Aspirations: An Experimental Study. Journal of Economic Behavior \& Organization, 74, 262276.

Michalos, A.C. (2008). Education, Happiness and Wellbeing. Social Indicators Research, 87(3), 347-366.

Neugarten, B., \& Neugarten, D. (1986). Policy Issues in Changing Society in the Adult Years, Continuity and Change. (APA Washington).

Powdthavee, N. (2008). How Much Does Money Really Matter? Estimating the Causal Effect of Income on Happiness. Discussion Paper in Economics no. 2009/02, University of York.

Repetto, R. (1986). Soil Loss and Population Pressure in Java. Ambio, 15(1), 14-18.

Roodman, D. (2011). Fitting Fully Observed recursive Mixed-process Models with CMP. The Stata Journal, 11(2), 159-206. . (2015). CMP: Stata module to implement conditional (recursive) mixed process estimator. Http://EconPapers.repec.org/Re Pec:boc:bocode:s456882.

Sarracino, F. (2012). Money, Sociability and Happiness: Social Erosion and Unhappiness? Time Series Analysis of Social Capital and Subjective Well-being in Western Europe, Australia, Canada and Japan. Social Indicator Research, 109, 135-188.

Seligman, M. (2003). Authentic Happiness: Using the New Positive Psychology to Realize Your Potential for Lasting Fulfillment. New York: Free Press.

Shon, K. (2010). Considering Happiness for Economic Development: Determinants of Happiness in Indonesia." KIEP Working Paper 1009, pp: 1-61.

Singer, M.A., W.M. Hopman, W.M., \& McKenzie, T.A. (1999). Physical Functioning and Mental Health in Patients with Chronic Medical Conditions. Quality of Life Research, 8(8), 687-691.

Sirgy, J. M. (1986). A Quality-of-Life Theory Derived from Maslow's Developmental Perspective. American Journal of Economics and Sociology, 45(3), 329-342.

Smyth, R., Nielsen, I., Zhai, O., Liu, T., Liu, Y., Tang, C., Wang, Z., Wang, Z., \& Zhang, J. (2011). A Study of the Impact of Environmental Sorroundings on Personal Well-Being in Urban China Using A Multi-item Well-Being Indicator. Population and Environment, 32(4), 353-375.

Stack, S., \& J. Eshleman, J. (1998). Marital Status and Happiness: A 17-Nation Study. Journal of Marriage and Family, 60(2), 527-536.

Stevenson, B., \& Wolfers, J., (2008). Economic Growth and Subjective Well-Being: Reassessing the Easterlin Paradox. Brookings Papers on Economic Activity, 2008, 1-87.

(2013). Subjective Well-being and Income: Is there any Evidence of Satiation? IZA Paper no. 7353.

Stutzer, A., \& Frey, B. S. (2010). Recent Advances in the Economics of Individual Subjective Well-Being. Social Research 77, 679-714.

Tian, G., \& Yang, L. (2007). A Formal Economic Theory for Happiness Studies: A Solution to the Happiness-Income Puzzle. Texas A\&M University, Department of Economics, College Station.

Tokuda, Y., \& Inoguchi, T. (2008). Interpersonal Mistrust and Unhappiness among Japanese People. Social Indicators, 89(2), 349-360. 
Ura, K., Alkire, S., Zangmo, T., and Wangdi, K. (2012). A Short Guide to Gross National Happiness Index. The Center for Bhutan Studies.

Van den Bergh, J. C.J.M. (2009). The GDP Paradox. Journal of Economic Psychology, 3, 117-135.

Veenhoven, R. (1988). The Utility of Happiness. Social Indicators Research, 20(4), 333-354.

------. (2006). How Do We Assess How Happy We Are? Tenets, Implications and Tenability of Three Theories. Paper presented at Conference on New Direction in the Study of Happiness, Unites States and International Perspectives, University of Notre Dame, USA.

(2008). Healthy Happiness. Effects of Happiness on Physical Health and Consequences for Preventive Health Care. Journal of Happiness Studies, 2008(9), 449-469. DOI 425-443, 10-1007/s 10902-006-9037-y

Williams, R. (2006). Generalized Ordered Logit/Partial Proportional Odds Models for Ordinal Dependent Variables. The Stata Journal 1, 58-82.

, (2010). Fitting Heterogeneous Choice Models with OGLM. The Stata Journal, 10(4), 540-567.

Youmans, E. G. (1977). The Rural Aged. Annals of the American Academy of Political and Social Science, 429, 81-90. 